\title{
Heteromolpadia joyceae, a new species of sea cucumber from New Zealand, with a key to New Zealand Molpadiidae (Echinodermata: Holothuroidea: Molpadiida)
}

\author{
DAVID L. PAWSON \& DORIS J. VANCE \\ National Museum of Natural History, Mail Stop MRC163, Smithsonian Institution, Washington DC 20013-7012, USA. \\ E-mail:pawsond@si.edu
}

\begin{abstract}
Heteromolpadia joyceae, new species, has been collected from depths of 258-632m off the east coast of New Zealand. It is distinctive in having a tough, leathery skin, gray with scattered red spots. Tables in body wall $100 \mu \mathrm{m}$ in diameter with three larger perforations; tail ossicles with 15-20 perforations, a three-pillared spire, and an average length of 300 $\mu \mathrm{m}$. A key to the eight species of Family Molpadiidae now known from the New Zealand region is provided.
\end{abstract}

Key words: Heteromolpadia joyceae, Holothuroidea, Molpadiida, New Zealand

\section{Introduction}

Molpadiid holothurians are distinctive, having a plump sausage-like body, a flat oral disc with a circle of 15 short tentacles, a conspicuous tail, and (usually) no tube feet, papillae, or tubercles. Many molpadiids are light to dark red, due to the presence in the body wall of masses of so-called phosphatic deposits. During growth of the animal, the calcite ossicles in the body wall gradually, and mysteriously, become transformed into light to dark red so-called phosphatic deposits. Thus as the animal grows, the body wall color may change from grayish to dark red as the calcite ossicles are supplanted by phosphatic deposits (Pawson, Donnay and Hey, 1975; Pawson, 1977). Chemical analysis has shown that phosphatic deposits consist mainly of ferric phosphate and ferric hydroxide (Mörner, 1902). The only ossicles that remain unaffected are those in the tail. In contrast, several molpadiid species lack phosphatic deposits, and the body remains grayish through the life of the animal.

The new species described here brings to eight the number of species now known from the New Zealand region (Pawson, 1963, 1965a, 1965b, 1970, 1977; McKnight et al., in press; Pawson, Vance and Davey, in preparation). In order to assist in identification of recently-collected New Zealand molpadiids, a key to the species is presented here. A monograph of the New Zealand holothurians (Pawson, Vance and Davey, in preparation) will include more details on all of the New Zealand molpadiid species.

Abbreviations used in the text: NIWA, National Institute of Water and Atmospheric Research, New Zealand (formerly NZOI, the New Zealand Oceanographic Institute); NMNZ, Museum of New Zealand Te Papa Tongarewa (formerly National Museum of New Zealand).

\section{Order Molpadiida Haeckel, 1896}

Remarks: The New Zealand region has a diverse fauna of molpadiids. This may reflect an intense collecting effort rather than indicating the region is especially well suited to colonization by molpadiids. Elsewhere, 
regional molpadiid faunas usually comprise two or three species. The last three species in the key below are all new records for the New Zealand region, merely listed in McKnight et al. (in press). These species were collected by NZOI and/or NMNZ, and they will be described in detail elsewhere (Pawson, Vance and Davey, in preparation).

\section{Key to holothurians of Family Molpadiidae from the New Zealand Region}

1. Ossicles in body wall include anchors and three-armed anchor plates, spired tables. Phosphatic deposits present. Genus Heteromolpadia Pawson, 1963...2

- Ossicles in body wall may include anchors and rosettes of racquet-shaped plates, fusiform rods, spired tables. No three-armed anchor plates. Phosphatic deposits present or absent

Genus Molpadia Risso, 1826...4

2. Tables in tail less than $200 \mu \mathrm{m}$ long, with 6-12 perforations. Complete tables usually present, but sometimes scattered, in body wall; diameter of tables usually exceeds $150 \mu \mathrm{m}$ 3

- Tables in tail approximately $300 \mu \mathrm{m}$ long, with $15-20$ perforations. Tables in body wall $100 \mu \mathrm{m}$ in diameter with three larger perforations, tables almost always transformed into phosphatic deposits

.. Heteromolpadia joyceae new species

3. Body wall tables of average diameter $300 \mu \mathrm{m}$, usually with more than 3 large perforations

Heteromolpadia pikei Pawson, 1965b

- Body wall tables of average diameter $150 \mu \mathrm{m}$, usually with only 3 large perforations ......

Heteromolpadia marenzelleri Théel, 1886

4. Phosphatic deposits absent or very rare; adult specimens gray, pink, or whitish. Body wall ossicles exclusively tables

- Phosphatic deposits present, usually numerous; adult specimens red to violet. Ossicles predominantly fusiform rods in body wall and tail. Spired tables and anchors with rosettes of racquet-shaped plates present in juveniles and young adults Molpadia musculus Risso, 1826

5. Spires of body wall tables single, solid, derived from 3 pillars fused together

- Spires of tables always composed of 3 discrete pillars, joined by crossbars but never fused together

Molpadia antarctica (Théel, 1886)

6. Tail ossicles circular, $75-160 \mu \mathrm{m}$ in diameter, often with only three perforations

- Tail ossicles rod-like, exceeding $300 \mu \mathrm{m}$ in length, with up to 20 perforations. Ossicles in body wall tables of average diameter $121 \mu \mathrm{m}$, with 3-8 perforations Molpadia abyssicola Pawson, 1977

7. Ossicles in body wall and tail exclusively tables with 3 perforations ...... Molpadia discors Pawson, 1977

- Ossicles in body wall and tail tables with 3-8 perforations ..Molpadia liska Pawson, 1977

\section{Family Molpadiidae Müller, 1850}

\section{Genus Heteromolpadia Pawson, 1963}

\section{Heteromolpadia joyceae, new species}

Figure $1 \mathrm{~A}-\mathrm{F}$

Molpadia ?n.sp. Pawson, 1965a: 13; 1977: 98.

Diagnosis: Body gray, typically with very numerous reddish spots approximately $1 \mathrm{~mm}$ in diameter. Body wall ossicles in young specimens three-armed anchor plates, anchors, and three-pillared tables $100 \mu \mathrm{m}$ in aver- 
age diameter with three larger perforations and often three additional smaller perforations. Body wall ossicles almost completely disappear as individuals grow. Tables in tail approximately $300 \mu \mathrm{m}$ long, with $15-20$ perforations.
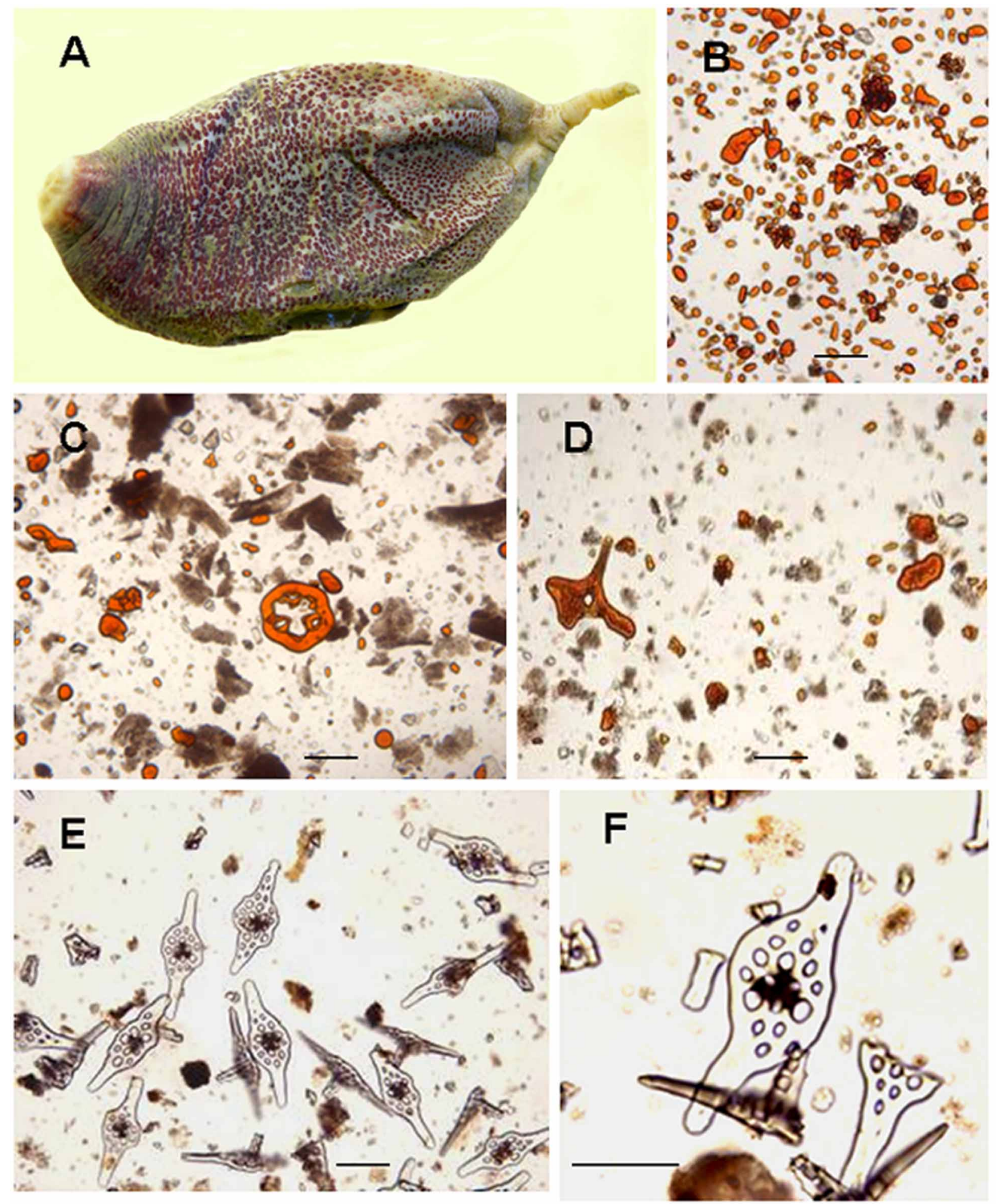

FIGURE 1. Heteromolpadia joyceae new species. A, Holotype, whole animal, total length $86 \mathrm{~mm}$. B, scattered phosphatic deposits derived from dissolution of skin in liquid household bleach. C, Remnants of a spired table with three larger perforations and three smaller. D, Fragments of three-armed anchor plate. E, Spired tables from tail. F, spired tables from tail, higher magnification. Scale line in Figures 1B-F $=100 \mu \mathrm{m}$. 
Material Examined: HOLOTYPE, Bay of Plenty, North Island, New Zealand, NZOI Station Z9005, 21

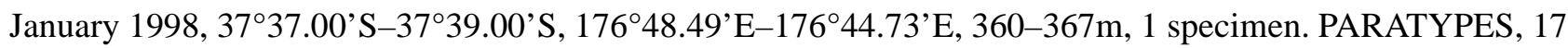
specimens: NZOI Station Z8999, 20 January 1998, 37³6.79'S-3847.00'S, $177^{\circ} 12.10^{\prime} \mathrm{E}-177^{\circ} 12.90^{\prime} \mathrm{E}, 460$

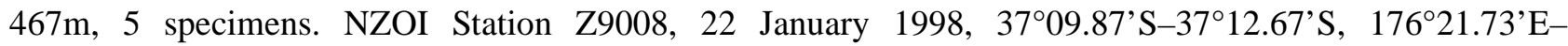

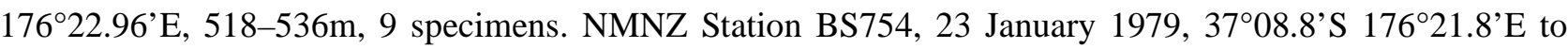
3709.4'S 176 23.8'E, 512-632m, mud, 1 specimen. NMNZ Station BS772, 27 January 1979, 39²17.2'S $178^{\circ} 12.7^{\prime} \mathrm{E}$ to $39^{\circ} 19.3^{\prime} \mathrm{S} 178^{\circ} 11.3^{\prime} \mathrm{E}, 258-306 \mathrm{~m}$, mud, 2 specimens.

Additional material: 67 specimens from 16 NZOI stations.

Description: Specimens typical of the Family Molpadiidae, although the tail is relatively long, occupying $17-30 \%$ of the total length of the body. Holotype (Figure 1A) $86 \mathrm{~mm}$ in total length, of which the tail occupies $16 \mathrm{~mm}$. In all specimens, total length is $48-120 \mathrm{~mm}$. Body wall smooth to touch, thin, but tough and leathery. Color in alcohol gray to dirty white, with very numerous light to dark red irregularly shaped spots (Figure 1A), which are aggregations of phosphatic deposits, each spot approximately $1 \mathrm{~mm}$ in diameter. Spots closely aggregated towards anterior end of body, more scattered posteriorly. Tail grayish-white, lacking red spots. Oral disk typical, with 15 tentacles, the disk diameter approximately $10 \%$ of body length.

In a 90mm long Paratype, calcareous ring with interradial pieces $5 \mathrm{~mm}$ high, radial pieces $7 \mathrm{~mm}$ high, of which relatively short posterior projections occupy $2 \mathrm{~mm}$. Posterior projections with narrow notch $0.5 \mathrm{~mm}$ deep. Polian vesicle single. Stone canal in mid-dorsal interradius whitish, approximately $7 \mathrm{~mm}$ long, madreporite approximately spherical, $0.5 \mathrm{~mm}$ in diameter. Pore canal $1 \mathrm{~mm}$ long extends from madreporite to attach to mid-dorsal body wall. Pore canal opens to exterior in an area distinguished by a bare gray patch approximately $10 \mathrm{~mm}$ posterior to oral disk. Gonad with few branches, genital duct opens to exterior in middorsal interradius, $1 \mathrm{~mm}$ posterior to oral disk. Gonad without ossicles. Course of intestine, and respiratory trees, typical.

Body wall in all specimens contains primarily clusters of phosphatic deposits (Figure 1B), derived from dissolution of calcareous ossicles. Rare remaining fragments of ossicles (Figures 1C-D) indicate that young specimens of this species carry in their body wall single anchor-plates that are apparently three-armed, along with typical molpadiid anchors. Fragments show that three-pillared tables of $100 \mu \mathrm{m}$ average diameter with three major perforations and often three smaller perforations are scattered in the body wall. Tail contains spired tables (Figure 1E-F) of average length $300 \mu \mathrm{m}$, with an oval central area with 15-20 perforations, and two rod-like extensions, usually imperforate. The three-pillared spire averages 60ìm in height.

Distribution: Off the east coast of the North Island, and the northeast coast of the South Island, and the Chatham Rise, in 258-632 meters. Apparently this species is confined to the bathyal zone.

Ecology: Like all other molpadiids, prefers mud substrates. In all specimens, the intestine is packed with mud.

Etymology: It is our pleasure to name this species for Mrs. Joyce McCullough of China Grove, North Carolina, as a small token of appreciation of her untiring, endlessly cheerful, volunteer assistance in the field and in the laboratory over the past several years.

Remarks: Pawson (1965a ) suspected that the two specimens he named "Molpadia ?n.sp." represented a new species, but noted that more material was needed in order to properly characterize the species. The abundant material now available confirms the validity of this new taxon. In having single three-armed anchor plates in the body wall, this species falls into the genus Heteromolpadia Pawson, 1963. From the Indonesian species H. tridens (Sluiter, 1901), H. joyceae differs in possessing spired tables in the body wall. Furthermore, in $H$. tridens the three-armed ossicles and anchors are retained to some extent as the animal grows, and apparently do not undergo extensive dissolution. $H$. joyceae differs from the other New Zealand congeners $H$. marenzelleri (Théel, 1886) and H. pikei Pawson, 1965b, in the nature of the ossicles in the tail; these are generally larger in $H$. joyceae, with far more numerous perforations (see key above). 


\section{Acknowledgements}

We are most grateful to the present and former staff of NIWA (formerly NZOI), in particular Dennis Gordon, Don McKnight, Helen Clark Rotman, and Steve O'Shea, for their help and kindness during the past 48 years. Similarly, we owe our thanks to the present and former staff of NMNZ, in particular Dr. Alan N. Baker, Director Emeritus. This research has been supported, in part, by Research Opportunities Funds and by the Scholarly Studies Program, Smithsonian Institution.

\section{References}

Haeckel, E.H. (1896) Systematische Phylogenie der Wirbellosen Thiere (Invertebrata). Zweiter Thiel des Entwurfs einer systematischen Stammasgeschichte. Berlin. 720 pp.

McKnight, D.G., Eagle, M.K., Pawson, D.L. Améziane, N., Clark, H.E.S., Alcock, N., \& Vance, D.J., (in press) Phylum Echinodermata. Sea-stars, brittlestars, sea urchins, sea cucumbers, sea lilies, and kin. In D. Gordon (Ed.) Species 2000, New Zealand. NIWA, New Zealand.

Mörner, C.T. (1902) Kleinere mittheilungen. 3. Die sagennanten weinrothen Körper der Holothurien. Hoppe-Seyler's Zeitschrift für Physiologische Chemie 37, 89-93.

Müller, J. (1850) Anatomischer Studien über die Echinodermen. Archiv für Anatomie und Physiologie 1850, 129-155.

Pawson, D.L. (1963) The holothurian fauna of Cook Strait, New Zealand. Zoology Publications from Victoria University of Wellington 36, 1-38.

Pawson, D.L. (1965a) The bathyal holothurians of the New Zealand region. Zoology Publications from Victoria University of Wellington 39, 1-33.

Pawson, D.L. (1965b) New sea-cucumbers (Echinodermata: Holothuroidea) from New Zealand waters. Records of the Dominion Museum Wellington 5(11), 75-82.

Pawson, D.L. (1970) The marine fauna of New Zealand: sea cucumbers (Echinodermata: Holothuroidea). New Zealand Department of Scientific and Industrial ResearchBulletin 201, 1-70.

Pawson, D.L. (1977) Molpadiid sea cucumbers (Echinodermata: Holothuroidea) of the Southern Atlantic, Pacific, and Indian Oceans. Antarctic Research Series Volume 26, Biology of Antarctic Seas 6, 97-123.

Pawson, D.L., Donnay, G.D. \& Hey, M. (1975) Iron phosphate deposits in molpadiid holothurians (Echinodermata: Holothuroidea). Biomineralization Research Reports 8, 16-20.

Risso, A. (1826) Histoire naturelle des principales productions de l'Europe méridionale et particulièrement de celles des environs de Nice et des Alpes maritimes. 5, 289-293. F.-G. Levrault, Paris.

Sluiter, C.P. (1901) Die Holothurien der Siboga-Expedition. Siboga Report 1, 1-142.

Théel, H. (1886) Report on the Holothurioidea. 2. Challenger Scientific Results. Zoology, 14, 1-290. 
